Karadeniz Uluslararası Bilimsel Dergi

Volume: 46, Summer-2020, p. (199-219)

ISSN: 1308-6200 DOI: https://doi.org/10.17498/kdeniz.689191

Research Article

Received: February 2, 2020 | Accepted: April 21, 2020

This article was checked by intihal.net.

\title{
MUHASEBE MESLEK MENSUPLARI VE ÇALIŞANLAR AÇISINDAN HAKSIZ REKABET
}

\section{UNFAIR COMPETITION IN ACCOUNTING PROFESSIONALSAND EMPLOYEES}

\section{НЕДОБРОСОВЕСТНАЯ КОНКУРЕНЦИЯ ПРИ ОТБОРЕ ПРОФЕССИОНАЛЛЬНЫХ БУХГАЛТЕРОВ И СОТРУДНИКОВ}

ÖZ

\author{
Filiz ASLAN ÇETIN" \\ Seyhan ÖZTÜRK ${ }^{* *}$
}

Küresel rekabet ortamında ayakta kalmaya ve yaşamını sürdürmeye çalışan kurumlar ya da bireyler yenilikçi hareket etmenin yanında çoğu zaman bu ortamın getirdiği çeşitli sorunlarla da karşı karşıya kalmaktadırlar. Genel olarak aynı alanda çalışan kişiler ya da kurumların en güçlü ve en başarılı olmak gibi aynı amaçlara ulaşmada karşılıklı yarış halinde olmaları rekabet olarak tanımlanmaktadır. Dolayısıyla haklı rekabette bilgi ve yeterlilik yarışı varken; haksız rekabette bilerek yaratılan ve meslek etiği ile bağdaşmayan durumlar söz konusu olabilmektedir.

$\mathrm{Bu}$ kavramlar etiğin oldukça önemli bir yere sahip olduğu muhasebe mesleği için değerlendirildiğinde normal rekabet ortamlarında mesleğin kimliğini üst noktalara çıkarma yarışı olarak düşünüldüğünde mesleğe oldukça değer katan bir durum oluşmaktadır. Ancak muhasebe meslek mensupları ve çalışanları arasında yaşanan haksız rekabet ise meslek etiğine aykırı davranışları, haksız kazançları ve üretmeden paylaşmayı kapsayarak; muhasebe meslek mensuplarına ve çalışanlarına hem maddi hem de manevi zarar vermektedir. Konunun bahsedilen önemi çerçevesinde yapılan bu çalışmada amaç; muhasebe meslek mensupları ve çalışanları açısından haksız rekabete sebep olabilecek faktörlerin incelenerek değerlendirilmesini sağlamaktır. Bu bağlamda rekabet ve haksız rekabet kavramları teorik açıdan etraflıca ele alınmış olup muhasebe meslek mensupları ve çalışanları açısından irdelenmiştir. Akabinde Kars, Ardahan ve Iğdır illerinde faaliyet gösteren muhasebe meslek mensupları ve çalışanları ile uygulama çalışması yapılmış, ortaya çıkan sonuçlar sunulmuştur.

Anahtar Kelimeler: Rekabet, Haksız Rekabet, Muhasebe Meslek Mensupları ve Çalışanları, Meslek Etiği, Türkiye Haksı Rekabetle Mücadele Kurulu.

\footnotetext{
" ORCID: 0000-0002-8210-799X, Kafkas Üniversitesi, İktisadi ve İdari Bilimler Fakültesi, İşletme Bölümü, Dr. Öğr. Üyesi (filizaslan79@gmail.com).

** ORCID: 0000-0003-1458-840X, Kafkas Üniversitesi, İktisadi ve İdari Bilimler Fakültesi, İşletme Bölümü, Doç.Dr. (seyhan87ozturk@gmail.com).
} 


\begin{abstract}
Institutions or individuals who try to survive and survive in a global competitive environment are often faced with various problems brought about by this environment. In general, it is defined as competition that individuals or institutions working in the same field are competing in achieving the same goals, such as being the strongest and most successful. Therefore, while there is a race of knowledge and competence in the right competition; There may be situations that are intentionally created in unfair competition and incompatible with professional ethics. When these concepts are evaluated for the accounting profession, where ethics has a very important place, considering the profession as a race to raise the identity of the profession in normal competitive environments, a situation that adds value to the profession occurs. However, unfair competition between professional accountants and employees includes behaviors contrary to professional ethics, unfair earnings and sharing without producing; It causes financial and moral damage to professional accountants and employees. In this study conducted within the framework of the importance of the subject, the aim is; to ensure that the factors that may cause unfair competition are examined and evaluated in terms of professional accountants and employees. In this context, the concepts of competition and unfair competition are handled theoretically in detail and examined in terms of professional accountants and employees. Subsequently, an application study was carried out with professional accountants and employees operating in Kars, Ardahan and Iğdır provinces, and the results were presented.

Keywords: Competition, Unfair Competition, Professional Accountants and Employees, Professional Ethics, Turkey Unfair Competitive Struggle Committee.
\end{abstract}

\title{
АННОТАЦИЯ
}

Учреждения или отдельные лица, которые пытаются выжить в глобальной конкурентной среде, часто сталкиваются с различными проблемами, вызываемыми этой же средой. В целом, это определяется как конкуренция, в которой отдельные лица или учреждения, работающие в одной и той же области, соревнуются для достижения сильнейших и наиболее успешных целей, Однако, при наличии честной гонки знаний и компетентности, могут быть применены намеренные ситуации для создания недобросовестной конкуренции несовместимые с профессиональной этикой. При оценках вышеуказанных подходов по отношению бухгалтерской профессии, в которой этика занимает очень важное место и рассматривая профессию как гонку, направленную на повышение идентичности профессии в нормальных конкурентных условиях, возникает ситуация, которая придает профессии большую ценность. Тем не менее, недобросовестная конкуренция между профессиональными бухгалтерами и их сотрудниками включает приводит к поведению, противоречащую профессиональной этике, приводящему к нечестным заработкам, что наносит финансовый и моральный ущерб профессиональным бухгалтерам и сотрудникам. В нижеследующем исследовании, проведенном в рамках важности предмета, рассмотриваются факторы, вызвающие недобросовестную конкуренцию, они оцениваются с точки зрения профессиональных бухгалтеров и работников. В этом контексте, понятия честной и недобросовестной конкуренции так же подробно рассматриваются профессиональными бухгалтерами и работниками. В последствии было проведено практическое исследование с участием профессиональных бухгалтеров и сотрудников, работающих в провинциях Карса, Ардахана и Игдыра, в соттветствии были представлены результаты. 


\section{Filiz ASLAN ÇETIN``Seyhan ÖZTÜRK}

Ключевые слова: конкуренция, недобросовестная конкуренция, профессиональные бухгалтеры и работники, профессиональная этика, Комитет борьбы против недобросовестной конкурентничи в Туричии.

\section{GİRIŞ}

Küreselleşme sonucu ortaya çıkan yeni ekonomik düzen içerisinde var olan rekabet kavramı genişlemiş ve yoğunluğu artmıştır. Bu ortamda işletmelerin ayakta kalabilmeleri, yeni rekabet sistemine ayak uydurabilme yeteneklerine bağlıdır. Bu ise performansı artırma ve rakipleri çok iyi analiz edebilme ile mümkün olmaktadır.

Bahsedildiği gibi modern ekonomik sistemlerde rekabet, temel bir olgu haline gelmiştir. Ancak rekabetin kurallarının olduğu ve ahlak, meslek ve hukuk kuralları çerçevesinde sürdürülmesi gerektiği bütün dünyada kabul edilmektedir. Maalesef işletmeler şiddetli rekabetin yaşandığı birçok pazarda kasten ya da bilmeyerek yanıltıcı ya da kurallara aykırı şekilde faaliyetlerini gerçekleştirip haksız rekabete yol açmaktadırlar.

Rakiplerin ürünleri hakkında yanlış bilgileri duyurmak, ehliyet ve iş yapabilirlik yeteneğine sahipmiş gibi görünmek ya da pazarda çok bilinen bir ürünü taklit etmeye çalışmak gibi haksız rekabet davranışının çoğu ülkede ortaya çıktığı görülmektedir. Bununla beraber, haksız rekabeti engellemek için birçok hukuki düzenleme hem ulusal hem de uluslararası platformda mevcuttur.

$\mathrm{Bu}$ bağlamda çalışma içerisinde önce rekabet ve haksız rekabet kavramları ile ilgili literatür bilgisine yer verilmiş, daha sonra muhasebe bilimi ve çalışanları açısından bu kavramların ne anlama geldiği tartışılmıştır. Araştırma bölümünde ise muhasebe meslek mensupları ve çalışanlarının haksız rekabet kavramı ile ilgili algıları ölçülerek sonuçlara yer verilmiştir.

\section{REKABET}

Fayda amaçlı gerçekleştirilen üretim, tarihte birçok farklı sorunla karşılaştığından kendini geliştirmek ve yenilemek zorunda kalmıştır. Yalnızca üretme ve ürettiğini satma olarak tanımlanan ilk süreçte, müsşeri memnuniyeti ya da müşteri elde etme gibi sorunlar olmadığından maliyet üzerine yoğunlaşılmıştır. Ancak daha sonraları müşteri talep ve ihtiyaçlarının farklılaşması, üretim yapan işletmeleri maliyet dışındaki verimlilik ya da kalite gibi faktörleri de değerlendirmek zorunda bırakmıştır. Zaman içerisinde üretim yapabilme ve müşteri taleplerinin karşılanması zorunlulukları işletmeleri yoğun bir rekabet ortamı ile baş başa bırakmıştır. Bu durum işletmelerin organizasyon yapılanmalarında da düzenleme yapılmasını gerektirmiştir.

Aslında rekabet kavramı, nadir bulunan ve kıt olan unsurların paylaşımı olarak tanımlanabilmektedir. Rekabet ortamı oluşabilmesi için her işletmenin kuruluş amacı ve değişen şartlara uyum sağlayabilecek bir yeteneğinin olması temel kriterlerdir. Rekabet bir yarıştır ve yarışta kalabilmek güçlü ve değişime uyumlu olmayı gerektirmektedir (Akyüz vd., 2010: 66).

Aynı zamanda rekabet kelimesi "aynı amaç sahibi olan kişi ya da kurumların arasında yaşanan yarış ya da çekişme" anlamına gelmektedir. Bu durum işletmelere uyarlandığında "mal ve hizmet piyasasındaki işletmelerin özgür bir ekonomik 


\section{Muhasebe Meslek Mensupları Ve Çalışanlar Açısından Haksız Rekabet}

ortamda karar vermesini sağlayan yarış" tanımı ortaya çıkmaktadır. Rekabet kavramı bağlamında insanın ya da işletmenin sürekli daha iyiyi talep ettiği göz önünde bulundurulursa bunun bir mücadele ortamı yarattı̆̆ını söylemek yanlış olmaz. Bu mücadele çoğu zaman ekonomik menfaatler üzerinde gerçekleşmekte ve kavram iktisadi bir içerik kazanmaktadır. Zira firsat eşitliği çerçevesinde sahip olunan soyut ve somut kaynaklara göre diğer işletmelerin önüne geçmek her zaman var olmuş meşru bir hedeftir (Tamer, 2010: 4).

Rekabetçilik ya da rekabet edebilirlik kavramı ise işletmelerin sahip olduğu kaynakları ve yetenekleri ile var olduğu sektörde bulunan rakipleri karşısında ayakta kalabilme ve mücadele edebilme durumunu ifade etmektedir. Diğer bir ifade ile rekabet edebilirlik, işletmenin tüketici isteklerini diğer işletmelere göre daha etkin şekilde analiz edebilmesi ve isteklerini karşlayabilmesi, yani mal ve hizmetlerini daha farklı, kaliteli ya da ucuz olarak pazara sunabilmesidir (Gürpınar ve Döven, 2007: 175).

Rekabet olgusunun daha da belirginleşip şiddetlendiği piyasalarda işletmelerin sürdürülebilir olmasının en temel koşulu değişimin zamanında gerçekleşmesi ve stratejilerin geliştirilmesidir. Tüketici yapısına uyum sağlamak, işletmeleri mutlak şekilde yeniden yapılanmaya itmiştir.

Rekabet doğrudan ya da dolaylı olarak pazarda bulunan bütün işletmelerin faaliyetlerini etkileyen ve koşulları belirleyen bir kavramdır. İşletmeler arası rekabette birçok faktör etkili olduğundan, işletmelerin amaçlarını buna göre belirlemesi esastır. Değişen rekabet anlayışı, üretim ile başlamış daha sonra kalite ve maliyet unsurları ile devam etmiş ve hizmet alanında daha da belirginleşmiştir. Günümüzde artık rekabet yoğunluğu ve çeşitliliği küreselleşmenin de etkisiyle sürekli artmaktadır (Tekin ve Çiçek, 2005: 63).

\section{HAKSIZ REKABET}

Global ekonomik sistem, piyasa ortamında işletmeleri sürekli değişim için zorlamaktadır. Ancak değişim piyasa ortamı ile sınırlandırılmamıştır, rekabette ve rakiplerde de sürekli değişim, gelişim ve yenileme söz konusudur. Eğer işletme bu değişim içerisinde bir rekabet avantajı elde etmiş ise bunu inovasyon ve gelişim ile desteklemek zorundadır, diğer türlü uzun dönem bu rekabet avantajını koruyamayacaktır. $\mathrm{Bu}$ bakış açısıyla değerlendirildiğinde işletmeler öncelikle rekabet edebilirliklerini korumak ve rekabetçi özelliklerini iyi bilmeli ve analiz etmelidir (Özşahin vd., 2005: 144).

Aslında insan ihtiyaç ve taleplerinin karşılanabilmesi için üretilen ürün ve hizmetlerin küresel pazarlara kolaylıkla sunulması iş dünyasında rekabet konusunu ön sıralara taşımıştır. Dolaylı ya da doğrudan yapılan rekabet, işletme faaliyetlerinin tümünü etkilemektedir. Özellikle bilgi ve iletişim teknolojisindeki hılı ve köklü değişimler, işletmeler için rekabeti bir yaşam biçimi haline getirmiştir. Rekabet baskısı işletmenin var olmak istediği pazarlardan büyük pay alma amac1, diğer işletmelerden her zaman önde olma isteği ve rakiplerinden farklı değerler yaratarak sadık müşteri topluluğu oluşturma hedefi ortaya çıkarmıştır. Ancak tüm bunlarla birlikte rekabet dürüstlük ve hakkaniyet ilkeleri çerçevesinde sürdürülmesi istenen 
bir olgudur. Bu yüzden çoğu zaman bu ilkelere uymadan gerçekleştirilen ve haksız rekabet olarak tanımlanan durumlar ortaya çıkmaktadır (Bakan ve Doğan, 2018: 1410).

Genel olarak bakıldığında, hızına yetişmekte güçlük çekilen teknolojik ve sosyolojik ilerlemeler, her geçen gün haksız rekabet kavramına yeni anlamlar kazandırmakta ve sınırlarının yeninden çizilmesine neden olmaktadır. Bu bakımdan haksız rekabet olarak kabul edilen durumların açıklanması için rekabet ve haksız rekabet kavramlarının çok iyi anlaşılması zorunludur (Tamer, 2010: 3).

Haksız rekabet kavrami; ekonomik alanda sürdürülen rekabetin iyi niyet kurallarına uyulmadan aldatıcı davranış ya da kurum ve toplum çıkarlarına zarar vererek rekabetin kötüye kullanılması olarak açıklanmaktadır. Haksız rekabet için yapılan düzenlemeler, özellikle işletmeler ve rekabet ettiği diğer işletmelerin haklarının korunması ve ekonomik düzenin sorunsuz işlemesini sağlamak için oluşturulmaktadır.

Bir haksız rekabet durumundan söz edebilmek için iktisadi bir rekabetten öncelikli olarak bahsedilmelidir. İktisadi rekabette taraf olan işletmeler üstün yönlerini gösterme çabasındadırlar. Bu üstünlüklerde müşteriler için sunulan mal ve hizmetlerin dolaylı olarak işletmenin tercih edilmesi için öne çıkarılmaktadır. İşletmeler fiyat, kalite, marka, reklam, diğer tutundurma çabaları ya da yenilikleri takip etme gibi özellikleri konusunda rekabet etmektedirler (Akpolat, 2015: 4).

Aslında haksiz rekabet kavram olarak ilk 1850'de Fransa'da ortaya çıkmıştır. Fransız İhtilali döneminde ticaretin sınırlandırılmadan yapılabilmesi için ticaret serbestisini ekonomik bir prensip olarak kabul etmişlerdir. Fakat bu durum birçok beklenmedik sonuç doğurmuş ve ticari işlemlere maruz kalan işletmelerin çıkarlarının korunması hususunda sorun yaşanmıştır. Bu anlamda haksız rekabetin engellenmesi kaçınılmaz hale gelmiştir.

$\mathrm{Bu}$ bağlamda rakip olsun olmasın ticari faaliyetlere taraf olabilecek her işletme ya da kişi için doğru ve sağlam bir rekabet sisteminin oluşturulması haksız rekabet düzenlemelerinin temel amacıdır. Aynı zamanda rakiplere zarar veren ya da tüketiciyi aldatma yoluna giden işletmelerin aykırı davranışları da haksız rekabet kapsamında ele alınmaktadır (Kacır, 2018: 49). Buna göre haksız rekabetten söz edebilmek için bir kazanç sağlamaya dönük bir yarışma ortamı ya da genel kabul görmüş ticaret kurallarına aykırı dürüst olmayan davranışlar olmalıdır (Bakan ve Doğan, 2018: 1415).

\section{MUHASEBE MESLEK MENSUPLARI VE ÇALIŞANLARI ARASINDA HAKSIZ REKABET}

"Rekabet; birlikte yaşayan insan topluluğu içinde kişiler arasında ortaya çıkan sosyal, ekonomik, politik ve daha birçok etkenden oluşan kapsamlı bir kavramdır. Haklı rekabet kavramı; bünyesinde bilgi, teknoloji, sistem, altyap1, yeterlilik, hizmet yarışlarını barındırmakta ve muhasebe mesleği için düşünüldügünde mesleğin itibarını daha üst pozisyonlara taşıma yarışı olarak görülmektedir". "Öte yandan meslek mensupları arasında yaşanan haksız rekabet ise meslekle bağdaşmayan durumları, haksız kazançları ve üretmeden paylaşmayı 


\section{Muhasebe Meslek Mensupları Ve Çalışanlar Açısından Haksız Rekabet}

kapsamaktadır. Böyle bir ortamda; meslek mensupları ciddi anlamda maddi ve manevi zarara uğramakta, mesleğin itibarı, saygınlı̆̆ ortadan kaldırmakta ve birtakım sorunların ortaya çıkmasına sebebiyet vermektedir" (Ar1, 2011: 66).

Muhasebe meslek mensupları arasında yaşanan haksız rekabet fiilleri temelde iki başlıkta toplanmaktadır.

- "Ücret Tarifesinden Kaynaklanan Haksız Rekabet: Muhasebe mesleği her zaman ekonomik gelişmelerden ve finansal krizlerden en fazla seviyede etkilenen hizmet sektörüdür. Uluslararası ekonomik gelişmeler, dövizde meydana gelen dalgalanmalar, ülkemizde uzun yıllar sonu gelmeyen ekonomik krizlere neden olmuş, bunlardan dolayı da muhasebe-müşavirlik hizmetlerinden doğan ücretlerinde zamanında tahsil edilememesi ya da hiç alınamaması, mükellef-meslek mensubu ilişkilerinde zayıflama, muhasebe meslek mensuplarının başka işlere yönelmesi vs. sonuçlarını doğurmuştur" (Gündüz, 2006:1).

- "Reklam ve Tanıtım Yoluyla Yapılan Haksız Rekabet: Yasal yönetmeliğe göre; meslek mensuplarının her türlü reklam ve reklam sayılabilecek fiil ve davranışlarda bulunması yasaklanmıştır. Ancak günümüz koşullarında; meslek mensuplarının bilerek ya da bilmeyerek bu tür eylemlere girdikleri de çoğu zaman görülebilmektedir" (Topçu, 2010: 40).

"Türkiye Haksız Rekabetle Mücadele Kurulu (TÜRHAK), haksız rekabet ile mücadele etmeyi amaç edinerek kurulmuş meslek içi bir kuruldur. Kurul aşağıda sıralanan bazı halleri özellikle haksız rekabet durumunun yaşandığını gösteren fiiller olarak kabul etmektedir." (TÜRHAK, 2011: 48-52):

- "Meslek mensuplarının dürüstlüğü, güvenilirliği ve tarafsızlığı hakkında yanlış beyanlarda bulunmak,"

- "Kendisi, hizmetleri ve faaliyetleri hakkında yanıltıcı açıklamalarda bulunmak,"

- "Sahip olmadığı meslek unvanını kullanmak",

- "Mesleki ve akademik unvan dışında sahip olunan başka unvanları kullanmak,"

- "Büro açılışlarını basın ve yayın yoluyla duyurmak"

Bunlardan başka muhasebe meslek mensupları arasında haksız rekabet ortamını doğuran diğer bazı faktörler de şunlardır (Ataman, 2010: 18):

- "Tahsilât sorunundan kaynaklanan haksız rekabet",

- "Defter tasdik ücretinden kaynaklanan haksız rekabet",

- "Meslek mensuplarının standartlara uymamasından kaynaklanan haksız rekabet",

- "Kamu denetimindeki yetersizlikten doğan haksız rekabet",

- "Mükelleflerin bilinç düzeyinden kaynaklanan haksız rekabet",

- "Mesleki mevzuattan kaynaklanan haksiz rekabet vb."

\section{ARAŞTIRMA}

$\mathrm{Bu}$ kısımda yapılan anket çalışmasından elde edilen veriler ve sonuçların değerlendirmeleri yer almaktadır. Demografik sorular ve haksız rekabet ile ilgili 
ifadeler şeklinde hazırlanan anket çalışmasını; katılımcıların gönüllülük esasına dayanmak suretiyle doldurmaları sağlanarak veri toplanmıştır. Elde edilen veriler SPSS 20 istatistik paket programı ile analiz edilmiştir.

\subsection{Araştırmanın Amacı ve Önemi}

Yapılan araştırmanın temel amacı, rekabet ve haksız rekabet konularına değinmek suretiyle Kars SMMMO'ya (Serbest Muhasebeciler ve Mali Müşavirler Odası) kayıtlı olan Kars, Ardahan ve Iğdır illerinde faaliyetlerini sürdüren muhasebe meslek mensupları ve çalışanlarının haksız rekabet konusu hakkındaki değerlendirmelerini tespit etmektir. Bu esas amacın yanı sıra ulaşılmaya çalışılan diğer amaçlar ise aşağıdaki gibi sıralanmaktadır:

- "Anket çalışmasına katkıda bulunanların demografik özelliklerini belirlemeye çalışmak",

- "Haksız rekabet konusu ile ilgili ifadelere katılımcıların katılma düzeylerini tespit etmek",

- "Haksiz rekabet konusundaki değerlendirmelerin hangi demografik özelliklere göre değişiklik gösterdiğini tespit etmektir”.

Katılımcılara yönelik adı geçen söz konusu bölgede daha evvel literatürde benzer bir anket çalışmasının yapılmamış olması çalışmayı özgün ve anlamlı kılmaktadır.

\subsection{Araştırmanın Kapsamı ve Kısıtları}

“Araştırmanın kapsamını Kars SMMMO'ya bağlı olarak Kars, Ardahan ve Iğdır illerinde faaliyet gösteren tüm muhasebe meslek mensupları ve çalışanlar oluşturmaktadır. Araştırma için hazırlanan anket formu tüm katılımcılara bizzat ulaştırılmış ve gönüllülük esasına dayanarak uygulanmıştır. Söz konusu anket formu; Ömürbek ve Türkoğlu'nun 2013 yılında yaptıkları "Muhasebe Meslek Mensupları Arasında Yaşanan Haksız Rekabet Üzerine Bir Araştırma" adlı çalışmadan faydalanılarak hazırlanmıştır".

Bilimsel çalışmaların genelinde olduğu gibi bu alan araştırmasında da çeşitli yönlerden birtakım sınırlamalar yer almaktadır. Bunlar;

- "Araştırma tasarımının kesitsel nitelikte olması ve belirli bir dönemi kapsaması, araştırmanın sınırlarından birini oluşturmaktadır. Bu bağlamda zaman kavramına dayanarak, meydana gelebilecek farklılıkları açıklamaktan uzak olduğu için net sonuçların çıkarılması mümkün görünmemektedir".

- "Araştırmadan elde edilen verilerin doğruluğu ve geçerliliği; veri toplama yöntemi için kullanılan anket formunda bulunan ifadeler, ifade cümlelerinin özellikleri ve kullanılan ölçek ile sınırlı tutulmuştur”.

- "Araştırma kapsamında tetkik edilen kavramlara bağlı olarak ölçüm araçlarının her ne kadar geçerliliği ve güvenilirliği olsa da sosyal bilimler yönünden bir kesinlik oluşturamadığı için, araştırma sonuçlarının 


\section{Muhasebe Meslek Mensupları Ve Çalışanlar Açısından Haksız Rekabet}

yorumlanabilmesi bakımından önem arz eden diğer bir kısıtı ortaya koymaktadır".

- "Araştırmadaki veriler ve ortaya çıkan bulgular, araştırmaya katılanlar ve onların anketteki ifadelere katılma düzeyleri ile sınırlı olmaktadır".

- "Bu çalışmadaki tüm bilgi, konuyla ilgili varılan yargı ve değerlendirmeler, faydalanılan bilimsel kaynaklar; istatistiksel analizlerin sonuçları, araştırmacının kullandığı bilimsel kaynaklar ve analiz sonuçlarına bağlı ulaştığı yargılar ile sınırlı tutulmuştur”.

\subsection{Araştırmanın Hipotezleri}

"Yapılan alan araştırmasında, nitel araştırma yöntemlerinden tanımlayıcı araştırma modeli kullanılmıştır. Tanımlayıcı araştırma; iki değişken arasındaki ilişkiyi göstermekte ve araştırmacının belirli bir zaman dilimi içerisinde elde ettiği bilgiler ile araştırdığı konuya ışık tutmaktadır. Bu bağlamda konunun sınırlarını belirlemekte ve görüntüsünü yansitabilmektedir" (Nakip, 2013: 180).

Araştırma için aşağıdaki gibi hipotezler geliştirilmiştir;

$\mathrm{H}_{0 \mathrm{a}}$ : Katılımcıların cinsiyeti ile haksız rekabet ifadelerine katılma düzeyleri arasında anlamlı bir farklılık bulunmamaktadır.

$\mathrm{H}_{1 \mathrm{a}}$ : Katılımcıların cinsiyeti ile haksız rekabet ifadelerine katılma düzeyleri arasında anlamlı bir farklılık bulunmaktadır.

$\mathrm{H}_{0 \mathrm{~b}}$ : Katılımcıların eğitim durumları ile haksız rekabet ifadelerine katılma düzeyleri arasında anlamlı bir farklılık bulunmamaktadır.

$\mathrm{H}_{1 \mathrm{~b}}$ : Katılımcıların eğitim durumları ile haksız rekabet ifadelerine katılma düzeyleri arasında anlamlı bir farklılık bulunmaktadır.

$\mathrm{H}_{0 c}$ : Katılımcıların unvanları ile haksız rekabet ifadelerine katılma düzeyleri arasında anlamlı bir farklılık bulunmamaktadır.

$\mathrm{H}_{1 \mathrm{c}}$ : Katılımcıların unvanları ile haksız rekabet ifadelerine katılma düzeyleri arasında anlamlı bir farklılık bulunmaktadır.

$\mathrm{H}_{0 \mathrm{~d}}$ : Katılımciların deneyimleri ile haksız rekabet ifadelerine katılma düzeyleri arasında anlamlı bir farklılık bulunmamaktadır.

$\mathrm{H}_{1 \mathrm{~d}}$ : Katılımcıların deneyimleri ile haksız rekabet ifadelerine katılma düzeyleri arasında anlamlı bir farklılık bulunmaktadır.

\subsection{Araștırmanın Yöntemi}

"Bilimsel çalışma sürecinde izlenilen yöntem, araştırmada elde edilen bulguların ve ulaşılan sonuçların anlamlı ve etkin bir biçimde ortaya konulabilmesi bakımından önemli görülmektedir. Dolayısıyla ilgili çalışmanın bu başlı̆̆ altında; araştırmanın ana kütlesi, bu ana kütleden yapılan örneklem seçimi, veri toplama yöntemi ve aracı, anketlerin geçerliliği ve güvenilirliği ile verilerin analizinde kullanılan yöntemler hakkında bilgilere yer verilmektedir".

\subsubsection{Araștırmanın Ana kütlesi ve Örneklemi}




\section{Filiz ASLAN ÇETIN``Seyhan ÖZTÜRK}

Alan çalışması kapsamında bulunan bu araştırmanın ulaşılabilir ana kütlesi (evren), 129 kişiden oluşmaktadır. Gönüllülük esasına dayalı olarak anketi doldurmayı kabul eden 79 kişidir.

"Araştırma için uygun bir örneklem belirlenirken; ana kütleyi iyi temsil edebilecek bir örneklem büyüklüğüne, örneklemin geçerlilik ve güvenilirlik düzeyinin yüksek olmasına, maliyete, zaman aralığına ve araştırma verilerinin analiz edilme koşullarına dikkat edilmiştir” (Padem vd., 2012: 63). Bu çerçevede araştırma örnekleminin tespitinde, olasılıklı örnekleme yöntemlerinden "basit tesadüfî örnekleme" yöntemi tercih edilmiştir.

"Araştırmanın örneklem büyüklügünün belirlenmesinde, örneklem hesaplama programından yararlanılmış ve örneklem büyüklüğü bu doğrultuda oluşturulmuştur. Örneklem büyüklüğünü hesaplamak için; eğer ana kütle büyüklüğü biliniyorsa, $\mathrm{n}=\left(\mathrm{Nt}^{\wedge} 2 \mathrm{pq}\right) /\left(\mathrm{d}^{\wedge} 2(\mathrm{~N}-1)+\mathrm{t}^{\wedge} 2 \mathrm{pq}\right)$ formülü kullanılmaktadır" (http://www.istatistiktezdestek.com, 14.11.2019). Örneklem hesaplama formülüne göre \%95 güven aralığında ulaşılması yeterli görülen örneklem sayısı 97 adet olup, uygulamanın zaman ve mekân kısıtları olması, bazı anketlerin de değersiz çıkması sonucu 72 adet anket analiz etmeye değer bulunmuştur.

\subsubsection{Araştırmanın Veri Toplama Yöntemi ve Aracı}

"Bu araştırmada, sosyal bilimler alanında yaygın olarak kullanılan ve birincil veri toplama yöntemlerinden biri olan anket yöntemi kullanılmıştır." Anket yöntemi ile araştırmanın hipotezlerini sınamak için seçilen temel veri toplama aracı ise öğrenciler ile yüz yüze yapılan görüşmelerde kullanılan anket formundan oluşmaktadır.

Araştırmada kullanılan anket formu, iki bölümden oluşmaktadır. Anketin birinci bölümünde, katılımcıların demografik özelliklerine yönelik 5 soru; ikinci bölümünde ise haksız rekabet konusunda 31 ifade bulunmaktadır.

Anket formunda aralık düzeyinde ölçümlere olanak sağlayan, 5'li Likert tipi ölçek kullanılmıştır. Çünkü 5'li Likert tipi derecelemeli ölçeğin, sosyal bilimler sahasında geniş bir kullanım alanı olduğu bilinmektedir. Ayrıca bu ölçek daha fazla, kişilerin eğilim ve tutumunu ölçmek için kullanılmaktadır (Büyüköztürk, 2010: 4). Dolayısıyla bu ölçek ile araştırmacı; katılımcıların anket formunda bulunan yargı cümlelerine karşı ne derecede eğilim ve tutum gösterdiğini ölçebilmektedir.

Anket formunda bulunan 31 adet ifadeye verilen yanitların katilma dereceleri; (1) "Kesinlikle Katılmiyorum", (2) "Katılmıyorum", (3) "Kararsızım", (4) "Katıliyorum", (5) "Kesinlikle Katılıyorum" üzerinden değerlendirme yapılmıştır.

Hazırlanan anketin ilk kısmında; katılımcıların cinsiyet, eğitim durumu, deneyim süresi, unvan, çalıştıkları il gibi demografik özelliklerle ilgili sorular yer almaktadır. İkinci kısımda ise haksız rekabet ilgili algı düzeyini ölçmeye yarayan 5'li Likert ölçeği çerçevesinde hazırlanan (5=kesinlikle katılıyorum, 1=kesinlikle katılmıyorum) 31 adet ifade yer almaktadır. 


\section{Muhasebe Meslek Mensupları Ve Çalışanlar Açısından Haksız Rekabet}

\subsubsection{Anketlerin Geçerlilik ve Güvenilirliği}

"Araştırma için geçerlilik; bir ölçme aracının amacına uygun, doğru ve yeterli düzeyde yantlar alabilme derecesini göstermektedir. Yani bir anket formunun neyi ölçtügünün ve neyi ne derecede iyi ifade ettiğinin göstergesi, geçerlilik kavramını açıklamaktadır. Bu kavram içerik, yapı ve kapsam geçerliliği olarak üç çeşit geçerlilikten oluşmaktadır" (Padem vd., 2012: 63). Bu araştırmada kullanılan anket formunun geçerliliğini sağlamak için bu konuda uzman birçok akademisyen, anket sorularının uygulanabileceği noktasında olumlu görüşünü bildirmiştir.

"Ölçme aracı olarak bir anket formunda bulunması gereken önemli bir özellikse anketteki soruların güvenilir olmasıdır. Çünkü güvenilirlik; bir anket formunda bulunan yargıların birbirleriyle olan tutarlılı̆̆ını ve kullanılan ölçeğin ilgilenilen sorunu ne derece yansıttığını ifade etmektedir. Dolayısıyla Cronbach's Alpha katsayısı 0 ile 1 arasında bir değer alıp, kullanılan ölçeğin güvenilirliği; 0.00 $\leq \alpha<0.40$ aralığında ise ölçeğin güvenilir olmadığı, $0.40 \leq \alpha<0.60$ aralığında ise ölçeğin güvenilirliğin düşük olduğu, $0.60 \leq \alpha<0.80$ aralığında ise ölçeğin oldukça güvenilir olduğu, $0.80 \leq \alpha<1.00$ aralığında ise ölçeğin yüksek derecede güvenilir olduğu yönünde yorumlanmaktadır" (Kalaycı, 2006: 403, 405).

"Bu bağlamda anket verilerinin içsel tutarlılığını ölçmek için yapılan güvenilirlik analizinde, Cronbach's Alpha katsayısı testi uygulanmıştır. Araştırma için Cronbach's Alpha katsayısı 0,87 olarak tespit edilmiş olup, bu katsayının 0.80 $\leq \alpha<1.00$ aralığında yer alması ölçeğin oldukça güvenilir olduğu, bu bağlamda ulaşılan araştırma bulgularının da güvenilirlik düzeyinin yüksek olacağı yargısına varılmaktadır".

\subsubsection{Analiz Yöntemi}

"Anket sonucunda elde edilen verilerin analiz edilmesi için SPSS 20 (Statistical Package for Social Sciences) istatistik paket programı kullanılmıştır. Hipotezlerin test edilmesinde, parametrik mi ya da parametrik olmayan (nonparametrik) testlerin mi kullanılacağını belirleyebilmek için verilerin, normal bir dağılım gösterip göstermediği incelenmiştir".

"Normal dağılım; sürekli bir dağılım olup burada gözlemler çan biçiminde olmakta ve ortalama etrafinda simetrik bir dağılım göstermektedir. Bu dağılımda birer ortalama türü olan aritmetik, mod ve medyan (ortanca) birbirine eşit olmaktadır (Nakip, 2013: 241). Nitel ve nicel değişkenlerin normal bir dağılım gösterip göstermediğini test edebilmek için; $Z$ istatistiği, Kolmogorov-Smirnov (K-S) ve Shapiro-Wilks testleri kullanılmaktadır. Buna göre çarpıklık katsayısının standart hatasına bölünmesi sonucunda $\mathrm{z}$ - istatistiğinin; $\alpha=0,05$ için 1,96 ve $\alpha=0,01$ için 2,58'den küçük çıkması durumunda, dağılımın normalden aşırı sapma göstermediği şeklinde yorumlanabilir. Eğer örneklem büyüklügü̈; 50'den küçük olursa ShapiroWilks testi, 50'den büyük olursa Kolmogorov-Smirnov testi kullanılmaktadır. Bu iki testte $\mathrm{p}$ değerinin 0,05 'ten büyük çıkması durumunda, bu anlamlılık düzeyinde puanların normal dağılımdan aşırı sapma göstermediği şeklinde yorumlanmaktadır" (Büyüköztürk, 2010: 42). 
“'Bu araştırmada örneklem büyüklüğü 50'den büyük olması nedeniyle Kolmogorov-Smirnov testi kullanılmıştır. Buna göre verilere normal dağılıma uygunluk testi yapılmıştır."

Kolmogorov-Smirnov test sonuçlarına göre, yarg1 cümlelerindeki veriler normal dağılım göstermemektedir. Çünkü test sonuçlarında yer alan anlamlılık düzeyleri her yargı cümlesi için 0,05 değerinden küçüktür. Başka bir ifade ile $\alpha=$ 0,05 anlamlılık düzeyinde $\mathrm{P}=0,000<0,05$ olduğu için normal dağılmadığı görülmüştür. Bu bağlamda veriler normal (simetrik) dağılım göstermedikleri için, parametrik olmayan testlerden Kruskal Wallis-H testinin kullanılması uygun görülmüştür.

Kruskal Wallis- H testi, parametrik olmayan testlerden tek yönlü varyans analizi yöntemidir. K bağımsız örneğin benzer ortanca değerli toplamların rastgele örnekleri olup olmadığını test etmekte kullanılmaktadır (Çolak, 2014: 50). Dolayısıyla bu analiz, ilişkisiz iki veya daha çok örneklem ortalamasının birbirinden anlamlı farkl111k gösterip göstermediğini test etmekte uygulanmaktadır (Büyüköztürk, 2010: 158).

Katılımcıların demografik özellikleri, betimleyici istatistiklerden frekans ve yüzde olarak açıklanmıştır. "Ankette yer alan ifadeler için; aralıkların eşit olduğu varsayımıyla, aritmetik ortalamalar için puan aralığı 0,80 olarak hesaplanmıştır (Puan Aralığ1 $=($ En Yüksek Değer - En Düşük Değer $) / 5=(5-4) / 5=4 / 5=$ 0,80 ). Buna göre oluşan değerlendirme aşağıdaki tabloya göre yapılmıştır" (Kaplanoğlu, 2014: 273).

Tablo.1 Aritmetik Ortalamaların Değerlendirme Aralı̆̆

\begin{tabular}{|c|c|}
\hline Aralık & Seçenek \\
\hline $1,00-1,80$ & $\begin{array}{c}\text { Kesinlikle } \\
\text { Kat1lmiyorum }\end{array}$ \\
\hline $1,81-2,60$ & Kat1lmıorum \\
\hline $2,61-3,40$ & Kararsizım \\
\hline $3,41-4,20$ & Kat1lyorum \\
\hline $4,21-5,00$ & Kesinlikle \\
\hline
\end{tabular}

Çalışmada frekans analizi, aritmetik ortalama, tek yönlü varyans analizi olan Kruskal Wallis $\mathrm{H}$ testi yapılmıştır.

\section{Araştırmada Elde Edilen Bulguların Analizi ve Değerlendirilmesi} 6.1 Araştırmaya Katılanların Demografik Özellikleri

Bulguların analiz edildiği bu kısımda; ilk olarak ankete katılanların demografik özellikleri aşağıda yer alan Tablo 2 ile sunulmuştur. 
Muhasebe Meslek Mensupları Ve Çalışanlar Açısından Haksız Rekabet

Tablo.2 Katılımcıların Demografik Özellikleri

\begin{tabular}{|l|c|c|}
\hline Cinsiyet & Frekans & Yüzde \\
\hline Kadın & 30 & 41,7 \\
\hline Erkek & 42 & 58,3 \\
\hline Ĕgitim & 8 & 11,1 \\
\hline Lise & 23 & 31,9 \\
\hline Ön lisans & 36 & 50,0 \\
\hline Lisans & 5 & 6,9 \\
\hline Yüksek lisans/ Doktora & & \\
\hline Deneyim & 25 & 34,7 \\
\hline $0-5$ yıl aras1 & 12 & 16,7 \\
\hline 6-10 y1l aras1 & 16 & 22,2 \\
\hline 11-15 y1l aras1 & 8 & 11,1 \\
\hline 16-20 yıl aras1 & 11 & 15,3 \\
\hline 21 y1l ve üzeri & & \\
\hline Çalıștığı İl & 45 & 0,62 \\
\hline Kars & 17 & 0,24 \\
\hline Ardahan & 10 & 0,14 \\
\hline Iğdır & & \\
\hline Unvan & 36 & 50 \\
\hline SMMM & 2 & 2,8 \\
\hline YMM & 34 & 47,2 \\
\hline Çalışan & 72 & 100 \\
\hline Toplam & & \\
\hline
\end{tabular}

Araştırmaya katılan muhasebe meslek mensupları ve çalışanların çoğunluğu erkek olup, lisans mezuniyetine sahip kişilerden oluşmaktadır. Yine örneklemin; 05 y1l arasi tecrübeye sahip olup daha çok Kars ilinde faaliyetini sürdüren ve en fazla SMMM unvana sahip katılımcılardan oluştuğu görülmektedir.

Araştırmaya katılan muhasebe meslek mensupları ve çalışanlara yöneltilen yargılara verdikleri cevapların değerlendirmeleri ise Tablo 3 'te yer almaktadır.

Tablo.3 Araştırmaya Katılanların Yöneltilen Yargılara Verdikleri Cevapların Değerlendirmeleri

\begin{tabular}{|c|c|c|c|}
\hline İFADELER & $\begin{array}{l}\text { Standart } \\
\text { Sapma }\end{array}$ & $\begin{array}{l}\text { Aritmetik } \\
\text { Ortalama }\end{array}$ & Değerlendirme \\
\hline 1. "Tahsilât sorunu yaşanmaktadır". & 1,21 & 3,84 & Kat1liyorum \\
\hline $\begin{array}{l}\text { 2. "Muhasebe mesleğinde başta ücret } \\
\text { olmak üzere birçok ekonomik unsur } \\
\text { üzerinden yapılan haksı rekabet } \\
\text { vardır". }\end{array}$ & 1,16 & 3,81 & Katıliyorum \\
\hline \begin{tabular}{lrr}
3. & \multicolumn{2}{c}{ "Meslek mensuplarından } \\
meslekleri dişında & eksperlik,
\end{tabular} & 1,13 & 3,68 & Kat1liyorum \\
\hline
\end{tabular}


Filiz ASLAN ÇETİN `Seyhan ÖZTÜRK

\begin{tabular}{|c|c|c|c|}
\hline $\begin{array}{l}\text { bilirkişilik, sigortacılık gibi diğer } \\
\text { işlerle uğraşmaktadır". }\end{array}$ & & & \\
\hline $\begin{array}{l}\text { 4. "Ülkemizde uygulanan VUK } \\
\text { meslek mensuplarına uygulamada } \\
\text { ağır sorumluluklar getirmekte bu } \\
\text { nedenle alınan KDV ve Stopaj } \\
\text { oranları daha makul seviyelere } \\
\text { çekilmelidir". }\end{array}$ & 1,09 & 3,75 & Katıliyorum \\
\hline $\begin{array}{l}5 . \quad \text { "Meslek mensuplarının } \\
\text { müşterilerine karşı fazla hoşgörülü } \\
\text { olmaları haksız kazançlara ve meslek } \\
\text { mensuplarının angarya olarak görülen } \\
\text { işlerle uğraşmasına neden } \\
\text { olmaktadır". }\end{array}$ & 1,13 & 3,79 & Katıliyorum \\
\hline $\begin{array}{l}\text { 6. "Meslek mensuplarının } \\
\text { kalitelerinde } \\
\text { oluşabilecek }\end{array}$ & 0,99 & 3,90 & Katıliyorum \\
\hline $\begin{array}{l}\text { 7. "Ruhsat kiralama yoluyla çalışan } \\
\text { meslek mensubu olmayan kişiler } \\
\text { bulunmakta ve bu kişiler haksız } \\
\text { rekabete neden olmaktadır". }\end{array}$ & 1,03 & 3,91 & Katıliyorum \\
\hline $\begin{array}{l}\text { 8. "Mükellef portföyüne göre } \\
\text { bulunduğunuz ilde meslek mensubu } \\
\text { sayıs fazladır". }\end{array}$ & 1,04 & 3,37 & Kararsızım \\
\hline $\begin{array}{l}\text { 9. "TÜRMOB tarafindan düzenlenen } \\
\text { haksız rekabet kongrelerinde } \\
\text { belirlenen ücret standartsızlıkları, etik } \\
\text { kuralların çiğnenmesi, kayıt dış1 } \\
\text { ekonomi gibi hususlar haksız rekabete } \\
\text { neden olan öncelikli sorunlardır". }\end{array}$ & 1,04 & 3,79 & Katıliyorum \\
\hline $\begin{array}{l}\text { 10. "Meslek mensuplarının kayıt dışı } \\
\text { ekonomi, vergi reformları, istihdam } \\
\text { ve işsizlik gibi önemli toplumsal } \\
\text { konularda çalışmalar yapması ve } \\
\text { sonuçlarının kamuoyuyla paylaşması } \\
\text { meslek itibarın yükseltilmesinde } \\
\text { büyük rol oynayacaktır". }\end{array}$ & 1,13 & 3,66 & Katıliyorum \\
\hline $\begin{array}{l}\text { 11. "Mesleki mevzuatın hazırlanması } \\
\text { ve sorunların tespit edilip çözümünde } \\
\text { mesleki örgüt yöneticileri ile meslek }\end{array}$ & 0,93 & 3,77 & Katıliyorum \\
\hline
\end{tabular}




\begin{tabular}{|c|c|c|c|}
\hline $\begin{array}{l}\text { mensupları arasında iletişimsizlikten } \\
\text { doğan aksaklıklar vardır". }\end{array}$ & & & \\
\hline $\begin{array}{l}\text { 12. "Meslek mensupları ile } \\
\text { mükellefler arasında iş yükü, müşteri } \\
\text { yapısı ve sayısını eşitleyecek bir } \\
\text { çalışma planının olmaması, başta yeni } \\
\text { işe başlayan meslek mensupları olmak } \\
\text { üzere tüm meslek mensupları arasında } \\
\text { haksız rekabete neden olmaktadır". }\end{array}$ & 1,18 & 3,70 & Kat1liyorum \\
\hline $\begin{array}{l}\text { 13. "Kamu Gözetimi, Muhasebe ve } \\
\text { Denetim Standartları Kurulu'nun } \\
\text { sağladığı uluslararası uyum, mesleki } \\
\text { vizyonu geliştiren önemli unsurlardan } \\
\text { biridir". }\end{array}$ & 1,00 & 3,65 & Kat1liyorum \\
\hline $\begin{array}{l}\text { 14. "TÜRMOB Üniversitenin } \\
\text { kurulması mali eğitimin eksikliğinden } \\
\text { doğan birçok mesleki sorunun ve } \\
\text { haksız rekabet } \quad \text { unsurlarının } \\
\text { oluşmasına engel olacaktır". }\end{array}$ & 1,12 & 3,61 & Kat1liyorum \\
\hline $\begin{array}{l}\text { 15. "Kamu denetiminin yapılmas1 } \\
\text { meslek mensuplarının ve } \\
\text { mükelleflerinin disiplin edilmesini ve } \\
\text { muhasebe-mali müşavirlik } \\
\text { hizmetlerindeki haksız fiilleri } \\
\text { engellemektedir". }\end{array}$ & 1,14 & 3,29 & Kararsızım \\
\hline $\begin{array}{l}\text { 16. "Yeni TTK'nin muhasebe ve } \\
\text { denetim konularındaki getirdiği yeni- } \\
\text { likler ve uluslararası uyum } \\
\text { çalışmaları, mesleğin saygınlığını art- } \\
\text { tıracak ve haksız fiile neden olan } \\
\text { standartsızlıkları ortadan kaldı- } \\
\text { rabilecek düzeydedir". }\end{array}$ & 1,00 & 3,40 & Kararsızım \\
\hline $\begin{array}{l}\text { 17. "Mesleki mevzuat içerisinde } \\
\text { haksız rekabete neden } \\
\text { olabilecek } \\
\text { unsurlar bulunmaktadır". }\end{array}$ & 1,14 & 3,62 & Kat1liyorum \\
\hline $\begin{array}{l}\text { 18. "TÜRMOB tarafindan meslek } \\
\text { mensuplarına yönelik hazırlanan } \\
\text { mesleki uzmanlık kursları meslek } \\
\text { mensupları arasında bilgi, tecrübe ve } \\
\text { eğitim konularından dolayı yaşanan } \\
\text { haksız rekabeti engelleyecektir". }\end{array}$ & 1,08 & 3,54 & Kat1lyorum \\
\hline $\begin{array}{l}\text { 19. "Meslek mensupları arasında } \\
\text { reklam yasağı yönetmeliğine ve tabela }\end{array}$ & 1,31 & 3,38 & Kararsızım \\
\hline
\end{tabular}


Filiz ASLAN ÇETİN `Seyhan ÖZTÜRK

\begin{tabular}{|c|c|c|c|}
\hline $\begin{array}{l}\text { standartlarına } \\
\text { bulunmaktadır". }\end{array}$ & & & \\
\hline $\begin{array}{l}20 . \quad \text { "Yeminli Mali Müşavirler } \\
\text { kanunda belirtilen işleri dışında diğer } \\
\text { muhasebe işleri ile (defter tutma gibi) } \\
\text { uğraşmaktadırlar". }\end{array}$ & 1,15 & 3,29 & Kararsızım \\
\hline $\begin{array}{l}\text { 21. "TÜRHAK' } 1 \text { haksız rekabet ile } \\
\text { ilgili sunduğu Büro Standartları } \\
\text { Yönetmeliği, E-Sözleşme ve Tahsilat } \\
\text { Yönetmeliği gibi yeni çözüm önerileri } \\
\text { haksı rekabeti engelleyecek } \\
\text { niteliktedir". }\end{array}$ & 1,14 & 3,22 & Kararsızım \\
\hline $\begin{array}{l}\text { 22. "Meslek mensupları mesleki tüm } \\
\text { ilke ve standartları taşımakta ve bu } \\
\text { çeccevede faaliyet sürdürmektedir". }\end{array}$ & 1,00 & 3,19 & Kararsızım \\
\hline $\begin{array}{l}\text { 23. "TÜRMOB tarafindan orta } \\
\text { vadede gerçekleştirilmek istenen } \\
\text { mesleki büro yönetim rehberi, } \\
\text { mesleki ekonomik ve } \\
\text { dayanışma kurumu projeleri meslek } \\
\text { mensupları ve muhasebe mesleği } \\
\text { üzerindeki haksız fiilleri ortadan } \\
\text { kaldırabilecektir". }\end{array}$ & 1,00 & 3,41 & Katıliyorum \\
\hline $\begin{array}{l}\text { 24. "TÜRMOB tarafından kısa } \\
\text { vadede yürürlüğe geçirilmesi istenen } \\
\text { Zaman Esaslı Ücret Tarifesi } \\
\text { Projesinin hazırlanmasında, iş } \\
\text { yükünün ve harcanan zamanın baz } \\
\text { alınması haksı ă kazançları } \\
\text { engelleyecek doğru bir çözüm } \\
\text { önerisidir." }\end{array}$ & 1,05 & 3,63 & Katıliyorum \\
\hline $\begin{array}{l}\text { 25. "Yılsonunda meslek mensupları } \\
\text { tarafından alınan defter tasdik ücreti } \\
\text { müşteri ilişkilerini zedelemekte ve } \\
\text { haksız rekabete neden olmaktadır." }\end{array}$ & 1,16 & 3,47 & Katıliyorum \\
\hline $\begin{array}{l}\text { 26. "Mesleki örgüt ve kuruluşların } \\
\text { yaptığı çalışmalar ve denetimler tüm } \\
\text { meslek mensuplarını kapsayacak } \\
\text { niteliktedir". }\end{array}$ & 1,13 & 3,41 & Katıliyorum \\
\hline $\begin{array}{l}27 . \quad \text { "Disiplin Yönetmeliğince } \\
\text { uygulanan disiplin cezaları haksız } \\
\text { rekabeti engelleyebilecek nitelikte ve } \\
\text { caydırıcı düzeydedir". }\end{array}$ & 1,18 & 3,22 & Kararsızım \\
\hline
\end{tabular}




\begin{tabular}{|c|c|c|c|}
\hline $\begin{array}{l}28 . \quad \text { "Mükellef-Meslek mensubu } \\
\text { arasındaki iş ilişskisi yapılan işlerin } \\
\text { sağllklı yürütülmesini sağlayacak } \\
\text { niteliktedir". }\end{array}$ & 1,10 & 3,47 & Kat1liyorum \\
\hline 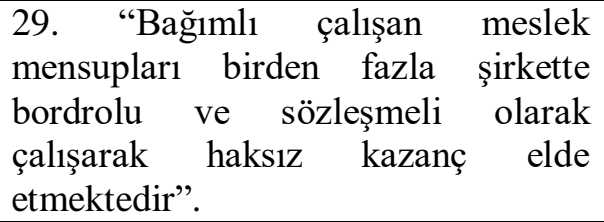 & 1,09 & 3,31 & Kararsızım \\
\hline $\begin{array}{l}\text { 30. "Ülkemizde doğru anlaş1lan ve } \\
\text { uygulanan muhasebe-denetim kültürü } \\
\text { bulunmaktadır". }\end{array}$ & 1,18 & 2,91 & Kararsızım \\
\hline $\begin{array}{l}\text { 31. "Mesleki mevzuatın yapısı meslek } \\
\text { mensuplarının tüm ihtiyaçlarını } \\
\text { karşılamakta ve sorunlarının } \\
\text { çözümünde yeterli olmaktadır". }\end{array}$ & 1,23 & 2,81 & Kararsızım \\
\hline
\end{tabular}

Tablodan görüldüğü üzere muhasebe meslek mensupları ve çalışanlarının genel olarak tahsilat sorunu yaşadığı, başta ücret olmak üzere birçok konuda haksız rekabet yaşadığı, meslekleri dışında işlerle uğraştıkları, haksız kazançlar sebebiyle angarya işlerle uğraşmak durumunda kalmaları, hizmet kalitesinde yaşanan düşüklük nedeniyle mesleki itibarın zedelendiği, çalışma ortamlarındaki plansızlık nedeniyle yeni işe başlayanlar arasında dahi haksız rekabet oluştuğu gibi sorunları yansıtan ifadelere katıldıkları görülmektedir. $\mathrm{Bu}$ noktada kamu gözetiminin, TÜRMOB tarafından düzenlenecek kursların, oluşturulacak eğitim rehberinin, hayata geçirilecek zaman esaslı ücret tarifesinin ve bu alanda yapılacak eğitim reformunun söz konusu yaşanan sorunların üstesinde gelebileceği konusunda fikir birliği içindedirler.

\subsection{Hipotezlerin Test Edilmesi}

$\mathrm{Bu}$ kısımda araştırmaya ait hipotezlerin test edilmesi, bulgular ve değerlendirmeler yer almaktadır.

$\mathrm{H}_{0 \mathrm{a}}$ : Katılımcıların cinsiyeti ile haksız rekabet ifadelerine katılma düzeyleri arasında anlamlı bir farklılık bulunmamaktadır.

$\mathrm{H}_{1 \mathrm{a}}$ : Katılımcıların cinsiyeti ile haksız rekabet ifadelerine katılma düzeyleri arasında anlamlı bir farklılık bulunmaktadır.

Tablo.4 Katılımcıların Haksız Rekabet İfadelerine Katılma Düzeylerinin Cinsiyetlerine Göre Değişimi

\begin{tabular}{|l|l|l|l|l|l|l|}
\hline \multirow{2}{*}{ Ífadeler } & Cinsiyet & $\mathbf{N}$ & $\begin{array}{l}\text { Sira } \\
\text { ortalamaları }\end{array}$ & Sd. & P. & $\mathbf{X}^{\mathbf{2}}$ \\
\hline \multirow{2}{*}{ İfade 1 } & Kadın & 30 & 28,33 & 1 & 0,003 & 8,691 \\
\cline { 2 - 7 } & Erkek & 42 & 42,33 & 1 & 0,025 & 5,042 \\
\hline İfade 6 & Kadın & 30 & 30,27 & 1 & &
\end{tabular}


Filiz ASLAN ÇETIN``Seyhan ÖZTÜRK

\begin{tabular}{|l|l|l|l|l|l|l|}
\hline \multirow{2}{*}{} & Erkek & 42 & 40,95 & & & \\
\hline & Toplam & 72 & & & \\
\hline
\end{tabular}

Analiz sonucuna göre $\mathrm{H}_{0 a}$ hipotezi 1. ve 6. ifadeler için ret, diğer ifadeler için kabul edilmektedir. Çünkü katılımcıların cinsiyetlerine göre ilgili ifadelere katılma düzeyleri arasında $\alpha=0,05$ anlamlllık düzeyinde; $\chi 2(\mathrm{sd}=1, \mathrm{~N}=72)=8,691$ ve $\mathrm{P}=0,003<0,05$ ve $\chi 2(\mathrm{sd}=1, \mathrm{~N}=72)=5,042$ ve $\mathrm{P}=0,025<0,05$ olduğundan istatistikî açıdan anlamlı bir farklılık bulunmaktadır. Söz konusu farklılık sıra ortalamaları daha yüksek olan erkek katılımcılardan kaynaklanmaktadır. Bu durum; tahsilât sorununun ve hizmet kalitesi düşmesinden yaşanan olumsuzlukların erkek katılımcıların daha yüksek sayıda olmasından dolayı ve bölgede bu meslekteki erkek sayısının daha fazla olmasından dolayı kaynaklanıyor olabilir.

$\mathrm{H}_{0 b}$ : Katılımcıların eğitim durumları ile haksız rekabet ifadelerine katılma düzeyleri arasında anlamlı bir farklılık bulunmamaktadır.

$\mathrm{H}_{1 b}$ : Katılımcıların eğitim durumları ile haksız rekabet ifadelerine katılma düzeyleri arasında anlamlı bir farklılık bulunmaktadır.

Tablo.5 Katılımcıların Haksız Rekabet İfadelerine Katılma Düzeylerinin Eğitim Durumlarına Göre Değişimi

\begin{tabular}{|c|c|c|c|c|c|c|}
\hline İfadeler & $\begin{array}{c}\text { Eğitim } \\
\text { Durumu }\end{array}$ & $\mathbf{N}$ & $\begin{array}{c}\text { Sira } \\
\text { Ortalamaları }\end{array}$ & Sd. & P. & $\mathrm{X}^{2}$ \\
\hline \multirow{4}{*}{ İfade 1} & Lise & 8 & 30,13 & \multirow{4}{*}{3} & \multirow{4}{*}{0,000} & \multirow{4}{*}{21,362} \\
\hline & Ön Lisans & 23 & 22,39 & & & \\
\hline & Lisans & 36 & 45,11 & & & \\
\hline & $\begin{array}{l}\text { Yüksek } \\
\text { Lisans / } \\
\text { Doktora }\end{array}$ & 5 & 49,60 & & & \\
\hline \multirow{4}{*}{ İfade 2} & Lise & 8 & 15,56 & \multirow{4}{*}{3} & \multirow{4}{*}{0,000} & \multirow{4}{*}{23,333} \\
\hline & Ön Lisans & 23 & 27,13 & & & \\
\hline & Lisans & 36 & 45,15 & & & \\
\hline & $\begin{array}{l}\text { Yüksek } \\
\text { Lisans / } \\
\text { Doktora }\end{array}$ & 5 & 50,80 & & & \\
\hline \multirow{4}{*}{ İfade 4} & Lise & 8 & 40,88 & \multirow{4}{*}{3} & \multirow{4}{*}{0,028} & \multirow{4}{*}{9,118} \\
\hline & Ön Lisans & 23 & 26,13 & & & \\
\hline & Lisans & 36 & 41,74 & & & \\
\hline & $\begin{array}{l}\text { Yüksek } \\
\text { Lisans / } \\
\text { Doktora } \\
\end{array}$ & 5 & 39,50 & & & \\
\hline \multirow{3}{*}{ İfade 5} & Lise & 8 & 47,13 & \multirow{3}{*}{3} & \multirow{3}{*}{0,006} & \multirow{3}{*}{12,330} \\
\hline & Ön Lisans & 23 & 26,83 & & & \\
\hline & Lisans & 36 & 37,63 & & & \\
\hline
\end{tabular}




\begin{tabular}{|c|c|c|c|c|c|c|}
\hline & $\begin{array}{l}\text { Yüksek } \\
\text { Lisans / } \\
\text { Doktora }\end{array}$ & 5 & 55,90 & & & \\
\hline \multirow{4}{*}{ İfade 6} & Lise & 8 & 35,81 & \multirow{4}{*}{3} & \multirow{4}{*}{0,003} & \multirow{4}{*}{14,263} \\
\hline & Ön Lisans & 23 & 24,11 & & & \\
\hline & Lisans & 36 & 43,14 & & & \\
\hline & $\begin{array}{l}\text { Yüksek } \\
\text { Lisans / } \\
\text { Doktora }\end{array}$ & 5 & 46,80 & & & \\
\hline \multirow{4}{*}{ İfade 7} & Lise & 8 & 36,88 & \multirow{4}{*}{3} & \multirow{4}{*}{0,030} & \multirow{4}{*}{8,956} \\
\hline & Ön Lisans & 23 & 26,61 & & & \\
\hline & Lisans & 36 & 41,42 & & & \\
\hline & $\begin{array}{l}\text { Yüksek } \\
\text { Lisans / } \\
\text { Doktora }\end{array}$ & 5 & 46,00 & & & \\
\hline \multirow{5}{*}{ İfade 21} & Lise & 8 & 54,50 & \multirow{4}{*}{3} & \multirow{4}{*}{0,013} & \multirow{5}{*}{10,729} \\
\hline & Ön Lisans & 23 & 38,24 & & & \\
\hline & Lisans & 36 & 33,65 & & & \\
\hline & $\begin{array}{l}\text { Yüksek } \\
\text { Lisans / } \\
\text { Doktora }\end{array}$ & 5 & 20,20 & & & \\
\hline & Toplam & 72 & & & & \\
\hline
\end{tabular}

Analiz sonucuna göre $\mathrm{H}_{0 b}$ hipotezi 1.,2.,4.,5.,6.,7., ve 21. ifadeler için ret, diğer ifadeler için kabul edilmektedir. Çünkü katılımcıların eğitim durumlarına göre ilgili ifadelere katılma düzeyleri arasında $\alpha=0,05$ anlamlılık düzeyinde; $\chi 2(\mathrm{sd}=3$, $\mathrm{N}=72)=21,362$ ve $\mathrm{P}=0,000 ; \chi^{2}(\mathrm{sd}=3, \mathrm{~N}=72)=23,333$ ve $\mathrm{P}=0,000 ; \chi^{2}(\mathrm{sd}=3$, $\mathrm{N}=72)=9,118$ ve $\mathrm{P}=0,028 ; \chi^{2}(\mathrm{sd}=3, \mathrm{~N}=72)=12,330$ ve $\mathrm{P}=0,006 ; \chi^{2}(\mathrm{sd}=3, \mathrm{~N}=72)$ $=14,263$ ve $\mathrm{P}=0,003 ; \chi 2(\mathrm{sd}=3, \mathrm{~N}=72)=8,956$ ve $\mathrm{P}=0,030$ ve son olarak $\chi 2(\mathrm{sd}=3$, $\mathrm{N}=72)=10,729$ ve $\mathrm{P}=0,013<0,05$ olduğundan istatistikî açıdan anlamlı bir farklılık bulunmaktadır. Genel olarak katılımcıların eğitim düzeyleri arttıkça verilen ifadelere katılımlarının farklılaştığı söylenebilir.

$\mathrm{H}_{0 c}$ : Katılımcıların unvanları ile haksız rekabet ifadelerine katılma düzeyleri arasında anlamlı bir farklılık bulunmamaktadır.

$\mathrm{H}_{1 \mathrm{c}}$ : Katılımcıların unvanları ile haksız rekabet ifadelerine katılma düzeyleri arasında anlamlı bir farklılık bulunmaktadır.

Tablo.6. Katılımcıların Haksız Rekabet İfadelerine Katılma Düzeylerinin Unvanlarına Göre Değișimi

\begin{tabular}{|l|l|l|l|l|l|l|}
\hline İfadeler & Unvan & $\mathbf{N}$ & $\begin{array}{l}\text { Sira } \\
\text { ortalamaları }\end{array}$ & Sd. & $\mathbf{p .}$ & $\mathbf{X}^{\mathbf{2}}$ \\
\hline İfade 27 & SMMM & 36 & 18,64 & 2 & 0,038 & 7,008 \\
\hline
\end{tabular}




\begin{tabular}{|l|l|l|l|l|l|l|}
\hline & YMM & 2 & 35,00 & & & \\
\cline { 2 - 4 } & Toplam & 38 & & & & \\
\hline
\end{tabular}

$\mathrm{Bu}$ noktada unvana sahip olan 38 katılımcı için bu analiz gerçekleştirilmiş çalışanlar kapsam dışı tutulmuştur. Analiz sonucuna göre $\mathrm{H}_{0 \mathrm{c}}$ yalnızca 27. ifade için ret, diğer ifadeler için kabul edilmektedir. Çünkü katılımcıların unvanlarına göre ilgili ifadeye katılma düzeyleri arasında $\alpha=0,05$ anlamlılık düzeyinde; $\chi 2(\mathrm{sd}=2$, $\mathrm{N}=38)=7,008 \mathrm{P}=0,038<0,05$ olduğundan istatistikî açıdan anlamlı bir farklılık bulunmaktadır. Burada 27. ifade olan; disiplin yönetmeliğince uygulanan disiplin cezalarının haksız rekabeti engelleyici olması konusunda özellikle unvan sahipleri arasında bir farklılaşmaya düştükleri görülmektedir.

$\mathrm{H}_{0 \mathrm{~d}}$ : Katılımciların deneyimleri ile haksız rekabet ifadelerine katılma düzeyleri arasında anlamlı bir farklılık bulunmamaktadır.

$\mathrm{H}_{1 \mathrm{~d}}$ : Katılımcıların deneyimleri ile haksız rekabet ifadelerine katılma düzeyleri arasında anlamlı bir farklılık bulunmaktadır.

Tablo.7. Katılımcıların Haksız Rekabet İfadelerine Katılma Düzeylerinin Deneyimlerine Göre Değiş̧imi

\begin{tabular}{|c|c|c|c|c|c|c|}
\hline İfadeler & $\begin{array}{l}\text { Deneyim } \\
\text { Süreleri }\end{array}$ & $\mathbf{N}$ & $\begin{array}{l}\text { Sura } \\
\text { Ortalamaları }\end{array}$ & Sd. & P. & $\mathbf{X}^{2}$ \\
\hline \multirow{5}{*}{ İfade 2} & $0-5$ y1l & 25 & 44,14 & \multirow{5}{*}{4} & \multirow{5}{*}{0,029} & \multirow{5}{*}{10,829} \\
\hline & 6-10 y11 & 12 & 43,42 & & & \\
\hline & $11-15 \mathrm{y} 11$ & 16 & 30,53 & & & \\
\hline & $16-20$ y1l & 8 & 26,25 & & & \\
\hline & $\begin{array}{l}21 \text { y1l ve } \\
\text { üzeri }\end{array}$ & 11 & 27,73 & & & \\
\hline \multirow{5}{*}{ İfade 14} & $0-5$ y1l & 25 & 31,34 & \multirow{5}{*}{4} & \multirow{5}{*}{0,025} & \multirow{5}{*}{11,147} \\
\hline & 6-10 y1l & 12 & 49,96 & & & \\
\hline & $11-15 \mathrm{y} 1 \mathrm{l}$ & 16 & 40,50 & & & \\
\hline & $16-20$ y1l & 8 & 23,00 & & & \\
\hline & $\begin{array}{l}21 \text { y1l ve } \\
\text { üzeri }\end{array}$ & 11 & 37,55 & & & \\
\hline Toplam & & 72 & & & & \\
\hline
\end{tabular}

Analiz sonucuna göre $\mathrm{H}_{0 \mathrm{~d}}$ hipotezi yalnızca 2. ve 14. ifadeler için ret, diğer ifadeler için kabul edilmektedir. Çünkü katılımcıların deneyim sürelerine göre ilgili ifadelere katılma düzeyleri arasında $\alpha=0,05$ anlamlılık düzeyinde; $\chi 2(\mathrm{sd}=4, \mathrm{~N}=72)$ $=10,829$ ve $\mathrm{P}=0,029$ ve $\chi 2(\mathrm{sd}=4, \mathrm{~N}=72)=11,147$ ve $\mathrm{P}=0,025<0,05$ olduğundan istatistikî açıdan anlamlı bir farklılık bulunmaktadır. Bu noktada başta ücret konusu olmak üzere birç̧ok konuda haksız rekabet yaşandığı ve TÜRMOB ile ilgili bir yüksek eğitim kurumunun oluşturulması halinde bu sorunun çözülebileceği konularında katılımcıların deneyimlerine göre bir farklılaşma yaşadıkları görülmektedir. 


\section{SONUÇ}

Günümüz küresel dünyasında rekabet hem işletmelere hem de kişilere avantaj sağlayan, hız kazandıran ve olumlu imaj yaratan bir kavram olarak öne çıkmaktadır. Rekabet konusunu iyi benimseyip, uygun şekilde davrananların rakiplerine göre büyük farklılık oluşturduğu görülmektedir. Bu tür sonuçlar tabi ki; rekabet olumlu anlamda değerlendirildiğinde oluşmakta haksiz rekabet söz konusu olduğunda ise aksi yönde etki göstermektedir. Maalesef günümüz rekabet ortamında haksız rekabet yaşandığı da görülmektedir. Bu çerçevede yapılan çalışmada Kars, Ardahan ve Iğdır bölgesinde Kars SMMMO'ya bağlı olarak faaliyet gösteren muhasebe meslek mensupları ve çalışanlarına konuya yönelik uygulama yapılmıştır. Yapılan çalışma ve katılımcılar kapsamında elde edilen sonuçlara göre;

- Yapılan uygulamaya katılanlar; genel olarak tahsilât anlamında sorunlar yaşandığını, birçok unsur üzerinden haksız rekabetin maalesef ki var olduğunu, haksız rekabetin haksız kazançlara yol açtığını, var olan haksız rekabet nedeniyle meslek mensuplarının; eksperlik, bilirkişilik, sigortacılık vb. farklı işlere yöneldiğini, hatta angarya görülen işlerle uğraşmak durumunda kaldıklarını ve ayrıca muhasebe hizmeti kalitesindeki düşüşün standartsızlığa ve haksız fiillere yol açtığ ifadelerine katılım göstermiştir.

- Bunların yanında mesleki örgüt ve kuruluşların yaptıkları denetimlerin yerinde ve yeterli olduğu, mükellef meslek mensubu ilişkilerinin sağlıklı olduğu gibi ifadelerde görüş birliği oluşturmuşlardır.

- Yaşanan haksız rekabet sorunlarının TÜRMOB tarafından düzenlenen seminerler, eğitimler vasitasıyla iyileştirilebileceği, TÜRHAK tarafindan yayımlanan yönetmeliğin haksız rekabeti önleyebilecek hususlara faydalı olacağ1 yönündeki ifadelere katılım göstermişlerdir.

- Ayrıca ifadelere katılımların demografik değişkenler içinde cinsiyet, eğitim düzeyi, tecrübe ve unvana göre farklılaştığı görülmüştür.

Bunların yanında TÜRHAK'ın mesleki itibarı ve imajı gölgeleyen bu hususa dair aldığ 1 hali hazırda önlemler rehberler halinde sunulmaktadır. Haksız rekabetle mücadele çalıştayları, kongreler, eğitimler ve denetimler ile bu durum giderek iyileştirilmeye çalışılmaktadır. Bu noktada bulunduğumuz bölge de faaliyet gösteren KARS SMMMO'nun haksız rekabetle mücadelede kurula gönderilen dosyaların son 3 yıla göre dağılımına bakıldığında; 2016 sıfır, 2017'de altı ve 2018'de sıfır dosya olduğu görülmektedir (https://www.turmob.org.tr, 12.12.2019). Bu tür çalışmalar ve alınacak önlemler ile daha iyi olacağı umulmaktadır.

\section{KAYNAKÇA}

Akpolat, T. (2015). Etik Yönelim ve Mesleğe Yeni Başlayanların Algısının Haksız Rekabet Davranışı Üzerine Etkisi: Muhasebeciler Üzerine Bir Araştırma. Yüksek Lisans Tezi. Gebze Teknik Üniversitesi, Sosyal Bilimler Enstitüsü.

Akyüz, K. C., Gedik, T., \& Akyüz, İ. (2010). Trabzon Arsin OSB'de Yer Alan İşletmelerin Rekabet Stratejileri ve Kalite Anlayışları. International Journal of Economic \& Administrative Studies, 2 (4), 65-81. 
Arı, H. (2011). Kurumsallaşma Sürecinde Haksız Rekabet. 3. Türkiye Haksız Rekabet Kongresi, TÜRMOB Yayınlar1 412, 66-71.

Ataman, B. (2010). Türkiye'de Kamu Denetimi ve Kamu Denetçilerine Genel Bakış. Maliye Finans Yazıları, 24 (87), 17-26.

Bakan, M. \& Doğan, İ.F. (2018). Rekabet ve Türk Ticaret Kanunu'nda Haksız

Rekabet. Social Sciences Studies Journal, 4 (16), 1409-1425.

Büyüköztürk, Ş. (2010). Sosyal Bilimler İçin Veri Analizi El Kitabı. Ankara: Pegem Akademi Yayınevi.

Gündüz, A. (2006). Hakslz Rekabet, Etik Kurallar ve Ücret Paradoksu. http://www.muhaseb etr.com/yazarlarimiz/ahmet/002/. (12.12.2019).

Gürpınar, K. \& Döven, M. S. (2007) Stratejik Yönetim Perspektifinden Türk Mobilya Sektörünün Rekabet Durumunun Analizi ve Değerlendirilmesi. Afyon Kocatepe Üniversitesi İktisadi ve İdari Bilimler Fakültesi Dergisi, 9 (1), 173-190. https://www.turmob.org.tr/FaaliyetRaporlari/turhak. (12.12.2019).

Kacır, S. (2018). Elektronik Ticarette Yanıltıcı Reklamların Haksız Rekabet Yaratıcı Etkileri. Yüksek Lisans Tezi. Eskişehir Osmangazi Üniversitesi, Sosyal Bilimler Enstitüsü.

Kalaycı, Ş. (2006). SPSS Uygulamalı Çok Değiş̧kenli İstatistik Teknikleri. Ankara: Asil Yayıncilik.

Kaplanoğlu, E. (2014). Muhasebe Stajyerlerinin Meslek Mensuplarından ve Meslek Örgütlerinden Beklentileri: Manisa İli Araştırması. Atatürk Üniversitesi İktisadi ve İdari Bilimler Dergisi, 28 (4), 265-284.

Nakip, M. (2013). Pazarlama Araştırmalarına Giriş (SPSS Uygulamalı). Ankara: Seçkin Yayınevi.

Ömürbek, V. \& Türkoğlu, T. (2011). Muhasebe Meslek Mensupları Arasında Yaşanan Haksız Rekabet Üzerine Bir Araştırma. Balıkesir Üniversitesi Sosyal Bilimler Enstitüsü Dergisi, 16 (30), 115-149.

Özşahin, M., Ciğerim, E., \& Gök, M. Ş. (2005). Rekabet Edebilirlik ve Firma Performansı İlişkisi Üzerine Bir Saha Araştırması. Gazi Üniversitesi İktisadi ve İdari Bilimler Fakültesi Dergisi, 7 (1), 143-155.

Padem, H., Göksu, A. \& Konakl1, Z. (2012). Araştırma Yöntemleri (SPSS Uygulamall). Saraybosna: IBU Publications.

Tamer, A. (2010). Yanlış veya Yanıltıcı Beyan ve Hareketlerle Haksız Rekabet. Yüksek Lisans Tezi. Ankara Üniversitesi, Sosyal Bilimler Enstitüsü.

Tekin, M., \& Çiçek, E. (2005). İşletmelerde Rekabet Üstünlüğü Sağlamada Farklı Bir Yaklaşım; Değer Temelli Pazarlama. İstanbul: V. Ulusal Üretim Araştırmaları Seтроzуити Bildiri Kitabl, 63-68.

Topçu, F. (2010). Muhasebe İşlerinde Haksız Rekabetin Boyutları ve Unsurları. 2. Türkiye Haksız Rekabet Kongresi, TÜRMOB Yayıları 379, 35-43.

Türkiye Haksız Rekabetle Mücadele Kurulu (TÜRHAK), (2011), Haksız Rekabetle Mücadelede Meslek Mensubunun Pusulas1, Ankara. 